\title{
Tissue Growth
}

National Cancer Institute

\section{Source}

National Cancer Institute. Tissue Growth. NCI Thesaurus. Code C16648.

An increase is the size or mass of a tissue due to an increase in cell number. 